\title{
A Study on Knowledge, Attitude and Practices of Emergency Physicians in Management of Patients with Mental Health Disorders in the City of Hyderabad, India
}

\author{
Akshay Bhargav', Imron Subhan', Namita Singh² \\ 'Clinic of Emergency Medicine, Apollo Hospitals, Jubilee Hills, Hyderabad, India \\ ${ }^{2} \mathrm{Clinic}$ of Neuropsychology, Apollo Hospitals, Jubilee Hills, Hyderabad, India
}

\begin{abstract}
Aim: To know if Emergency Physicians (EPs) screen mental health (MH) disorders in patients. This study aims at finding out the current knowledge, attitude and practices (KAP) of EPs and their departmental policies in management of patients with MH disorders.

Materials and methods: A personal interview based on a questionnaire was conducted with 117 EPs working in 38 multi-specialty hospitals (with minimum 50 total bed strength) across Hyderabad city, India during June 2015 to August 2015. The respondents had at least one year of experience in core emergency medicine.

Results: $85 \%$ of EPs understand MH disorders are a major healthcare burden and over $90 \%$ of them have seen mentally ill patients in Emergency Department (ED). Yet $85 \%$ rarely evaluate $\mathrm{MH}$ of patients. Over $2 / 3^{\text {rd }}$ don't know any criteria of diagnosing depression and only $14 \%$ have received some training in managing $\mathrm{MH}$ issues of patients. $84 \%$ physicians said that their departments do not have a $\mathrm{MH}$ policy and $82 \%$ believe this is a major reason that evaluation of $\mathrm{MH}$ is ignored. $44 \%$ EPs say their attitude towards these patients is influenced by their personal experiences.
\end{abstract}

Conclusion: MH evaluation of patients is neglected in EDs. Overall management of mentally ill patients is inconsistent. Absence of a departmental MH policy and lack of training in EPs are major causes.

Keywords: Mental health evaluation, emergency physicians, emergency departments, knowledge attitude practices, mental health disorders

\section{Introduction}

Mental health $(\mathrm{MH})$ disorders are a major cause of morbidity and disease burden affecting over 450 million people worldwide (1). The government of India estimates, in its MH policy, that 2 out of 10 Indians are likely to suffer from some form of mental illness by the year 2020 (2). Depression has been linked to common conditions that present to the Emergency Department (ED) such as cardio-vascular illnesses, stroke, COPD, diabetes, chronic kidney disease, and cancer (3-9). As such, the prevalence of depression was found to be higher in ED patients when compared to the general population (10). Mental disorders, if unattended to, can lead to a worse outcome of the primary illness and has been linked to longer hospital stays as these patients show poor levels of self-care (11).

Patients presenting with deliberate self-harm or suicidal attempts are not uncommon to the ED and the cause is often attributed to mental illnesses (12). The Indian National Crime Bureau Records reports more than 100,000 deaths due to suicide in the country every year from 2004 to 2014 (13). Suicide was the second leading cause of death among 1529 year olds globally in 2012 (14). Children and adolescents may also present with non-psychiatric problems as such somatization, behavioral disturbances, or substance abuse (15). In India, there is approximately one psychiatrist per $200,000-300,000$ people (16). Seeking professional help requires insight and motivation, and that becomes even more difficult with underlying social stigmas and poor awareness in society (1719). As such, these patients end up in the ED in moments of crisis.

To address the gap between increasing the burden of mental illnesses and limited resources, the WHO suggests that primary diagnosis and basic management of $\mathrm{MH}$ disorders be done by primary care physicians (20). This becomes more relevant in the Indian scenario because Emergency Medicine is a new specialty. Newly established EDs are increasing in the country and it is essential that our programs and policies be more sensitive to the patients' needs. Screening patients for MH disorders in the ED is recommended $(21,22)$.

Hyderabad is a major Indian city with a population over 3.9 million (23). As there are no studies on MH assessment in ED in India, we

Correspondence to: Akshay Bhargav e-mail: drakshaybhargav@gmail.com 
Table 1. Exposure and awareness to MH disorders

\begin{tabular}{|l|c|c|c|}
\hline \multicolumn{1}{|l|}{ Question } & Yes & No & Uncertain \\
\hline $\begin{array}{l}\text { Q1. } \\
\begin{array}{l}\text { Have you seen a mentally ill } \\
\text { patient in your ER that needed } \\
\text { better treatment? }\end{array}\end{array} \begin{array}{c}106 \\
(90.6 \%)\end{array}$ & $\begin{array}{c}11 \\
(9.4 \%)\end{array}$ & N/A \\
\hline $\begin{array}{l}\text { Q2. Do you believe Mental illnesses } \\
\text { are a major healthcare burden? }\end{array}$ & $\begin{array}{c}99 \\
(84.7 \%)\end{array}$ & $\begin{array}{c}6 \\
(5.1 \%)\end{array}$ & $\begin{array}{c}12 \\
(10.2 \%)\end{array}$ \\
\hline MH: mental health; ER: emergency room & & \\
\hline
\end{tabular}

Table 2. Evaluation and referral of $\mathrm{MH}$ patients

\begin{tabular}{|c|c|c|c|c|}
\hline & Question & Yes & No & Uncertain \\
\hline Q1. & $\begin{array}{l}\text { Is there a management/ referral } \\
\text { policy in your department for } \\
\text { mentally ill patients? }\end{array}$ & $\begin{array}{c}19 \\
(16.2 \%)\end{array}$ & $\begin{array}{c}98 \\
(83.8 \%)\end{array}$ & $\mathrm{N} / \mathrm{A}$ \\
\hline Q2. & $\begin{array}{l}\text { Do you think } \mathrm{MH} \text { assessment is } \\
\text { ignored due to absence of } \\
\text { departmental protocols? }\end{array}$ & $\begin{array}{c}96 \\
(82.1 \%)\end{array}$ & $\begin{array}{c}7 \\
(5.9 \%)\end{array}$ & $\begin{array}{c}14 \\
(12.0 \%)\end{array}$ \\
\hline Q3. & $\begin{array}{l}\text { Do you think that it is difficult } \\
\text { to evaluate MH because of lack } \\
\text { of time or busy ER environment? }\end{array}$ & $\begin{array}{c}78 \\
(66.6 \%)\end{array}$ & $\begin{array}{c}19 \\
(16.2 \%)\end{array}$ & $\begin{array}{c}20 \\
(17.1 \%)\end{array}$ \\
\hline Q4. & $\begin{array}{l}\text { Do you give any discharge } \\
\text { advice to patients regarding } \\
\text { their mental illness? }\end{array}$ & $\begin{array}{c}53 \\
(45.3 \%)\end{array}$ & $\begin{array}{c}64 \\
(54.7 \%)\end{array}$ & $\mathrm{N} / \mathrm{A}$ \\
\hline
\end{tabular}

Table 3. Knowledge and training assessment

\begin{tabular}{|c|c|c|c|c|}
\hline & Question & Yes & No & Uncertain \\
\hline Q1. & $\begin{array}{l}\text { Have you received formal } \\
\text { training in managing people } \\
\text { with depression or mental } \\
\text { disorders? }\end{array}$ & $\begin{array}{c}16 \\
(13.7 \%)\end{array}$ & $\begin{array}{c}101 \\
(86.3 \%)\end{array}$ & $\mathrm{N} / \mathrm{A}$ \\
\hline Q2. & $\begin{array}{l}\text { Do you know of any criteria for } \\
\text { diagnosing depression? }\end{array}$ & $\begin{array}{c}37 \\
(31.6 \%)\end{array}$ & $\begin{array}{c}80 \\
(68.4 \%)\end{array}$ & $\mathrm{N} / \mathrm{A}$ \\
\hline Q3. & $\begin{array}{l}\text { Do you use any scale or tool to } \\
\text { diagnose depression? }\end{array}$ & $\begin{array}{c}21 \\
(17.9 \%)\end{array}$ & $\begin{array}{c}96 \\
(82.1 \%)\end{array}$ & $\mathrm{N} / \mathrm{A}$ \\
\hline Q4. & $\begin{array}{l}\text { Are you aware of non - } \\
\text { pharmacological management } \\
\text { of depression? }\end{array}$ & $\begin{array}{c}74 \\
(63.2 \%)\end{array}$ & $\begin{array}{c}43 \\
(36.8 \%)\end{array}$ & $\mathrm{N} / \mathrm{A}$ \\
\hline Q5. & $\begin{array}{l}\text { Do you feel that due to lack of } \\
\text { training or knowledge the } \\
\text { identification of mental illness } \\
\text { can be difficult? }\end{array}$ & $\begin{array}{c}88 \\
(75.2 \%)\end{array}$ & $\begin{array}{c}15 \\
(12.8 \%)\end{array}$ & $\begin{array}{c}14 \\
(12.0 \%)\end{array}$ \\
\hline
\end{tabular}

In reference to Table 3, Q1 - 12 out of the 16 EPs who said yes quoted their postgraduate curriculum in emergency medicine as formal training.

In reference to Table 3 Q3 - 15 out of the 21 EPs who said yes quoted using SADPER-

SONS score when dealing with patients with deliberate self-harm.

felt it important to obtain baseline data in Hyderabad. Therefore, this study aims at learning the knowledge, attitude, and practices (KAP) of Emergency Physicians (EPs) in the management of patients with $\mathrm{MH}$ disorders in one major Indian city.

\section{Materials and Methods}

This is an observational study where a survey was carried out during the months of June to August, 2015. 40 multi-specialty
Table 4. Correlation analysis to understand the impact of knowledge of criteria for diagnosing depression and the $\mathrm{MH}$ evaluation practices

\begin{tabular}{|c|c|c|c|}
\hline & $\begin{array}{l}\text { EPs knowing } \\
\text { criteria for } \\
\text { diagnosing } \\
\text { depression }\end{array}$ & $\begin{array}{l}\text { EPs not knowing } \\
\text { criteria for } \\
\text { diagnosing } \\
\text { any depression }\end{array}$ & Total \\
\hline $\begin{array}{l}\text { EPs evaluating } \mathrm{MH} \text { of } \\
>10 \text { patients/month }\end{array}$ & 8 & 8 & 16 \\
\hline $\begin{array}{l}\text { EPs evaluating } \mathrm{MH} \text { of } \\
<10 \text { patients/month }\end{array}$ & 29 & 72 & 101 \\
\hline Total & 37 & 80 & 117 \\
\hline \multicolumn{4}{|c|}{$\begin{array}{l}\text { Odd's ratio: } 2.48 \text {. Suggests physicians knowing criteria of diagnosing depression are } \\
\text { more likely to evaluate mental health of patients in Emergency Room } \\
\text { EPs: emergency physicians; } \mathrm{MH} \text { : mental health }\end{array}$} \\
\hline
\end{tabular}

hospitals were included in the study having minimum total bed strength of 50 .

This study did not interfere with existent patient care and no patient data was acquired. Only the Emergency physicians were interviewed.

An oral informed consent was taken from the medical superintendent or the Head of the ED. 38 Hospital authorities consented to the study. Our target population was EPs who had at least 1 year of experience in core emergency medicine. $117 \mathrm{EPs}$ consented to participate in the study. It was explained that the confidentiality of the institute and the respondents will be maintained.

Prior to the main study a pilot survey was done at a national conference where 25 EPs from 10 different Indian cities were questioned. The pilot study helped in improving the questionnaire.

The study investigator met with each of 117 doctors and provided the questionnaire. A personal interview was conducted and direct feedback was taken. The questionnaire had 15 parts mostly based on a yes or no option. Few questions allowed descriptive answers. One major question had several sub questions where EPs were required to answer on basis of their experiences.

Data from the questionnaire was tabulated and analysis done using Microsoft Excel software. Results were later reproduced in form of tables and pie charts.

This study was approved by Institutional Ethics Committee Clinical studies of Apollo Hospitals, Hyderabad.

\section{Results}

The data obtained from the questionnaire are presented in Table 1 (estimating exposure and disease awareness), in Table 2 (practices in evaluation and referrals), in Table 3 (training and knowledge), and in Table 4 (attitude).

EPs were asked to explain their reason for seeking psychiatric referrals, to which $80 / 117$ responded. The responses were variable; yet, deliberate self-harm or suicidal attempt was the most common reason for psychiatric referral quoted by $55 / 80$ physicians. EPs were also asked to elaborate the discharge advice they gave to patients regarding their mental illness. 35/53 responded with answers like "counseling the patient," (14/35) "counseling the family," "avoiding the trigger," and "exercise and meditation."

\section{Resources availability}

102/117 (87.2\%) physicians said their hospital has a psychiatrist available during OPD hours, but not $24 / 7$. Less than $20 \%$ of hospitals 
Table 5. Attitude towards MH disorders

\begin{tabular}{|c|c|c|c|c|}
\hline & Question & Yes & No & Uncertain \\
\hline Q1. & $\begin{array}{l}\text { Do you think EPs have no role } \\
\text { in management of mental } \\
\text { illnesses? }\end{array}$ & $\begin{array}{c}14 \\
(12.0 \%)\end{array}$ & $\begin{array}{c}79 \\
(67.5 \%)\end{array}$ & $\begin{array}{c}24 \\
(20.5 \%)\end{array}$ \\
\hline Q2. & $\begin{array}{l}\text { Do you feel patients with } \mathrm{MH} \\
\text { disorders are treated as } \\
\text { unwelcome in ER? }\end{array}$ & $\begin{array}{c}47 \\
(40.2 \%)\end{array}$ & $\begin{array}{c}35 \\
(29.9 \%)\end{array}$ & $\begin{array}{c}35 \\
(29.9 \%)\end{array}$ \\
\hline Q3. & $\begin{array}{l}\text { Do you feel the awareness } \\
\text { about MH disorders is very } \\
\text { poor in ER staff? }\end{array}$ & $\begin{array}{c}71 \\
(60.7 \%)\end{array}$ & $\begin{array}{c}17 \\
(14.5 \%)\end{array}$ & $\begin{array}{c}29 \\
(24.8 \%)\end{array}$ \\
\hline Q4. & $\begin{array}{l}\text { Is your approach to patients } \\
\text { with mental illness influenced } \\
\text { by your own personal (not } \\
\text { clinical) experiences in } \\
\text { handling the same? }\end{array}$ & $\begin{array}{c}52 \\
(44.4 \%)\end{array}$ & $\begin{array}{c}32 \\
(27.4 \%)\end{array}$ & $\begin{array}{c}33 \\
(28.2 \%)\end{array}$ \\
\hline Q5. & $\begin{array}{l}\text { Have you experienced that } \\
\text { patients or their family DO NOT } \\
\text { take the advice for a psychiatric } \\
\text { referral kindly? }\end{array}$ & $\begin{array}{c}69 \\
(58.9 \%)\end{array}$ & $\begin{array}{c}15 \\
(12.8 \%)\end{array}$ & $\begin{array}{c}33 \\
(28.2 \%)\end{array}$ \\
\hline
\end{tabular}

Q. How often do you evaluate mental health of a patient in ED?

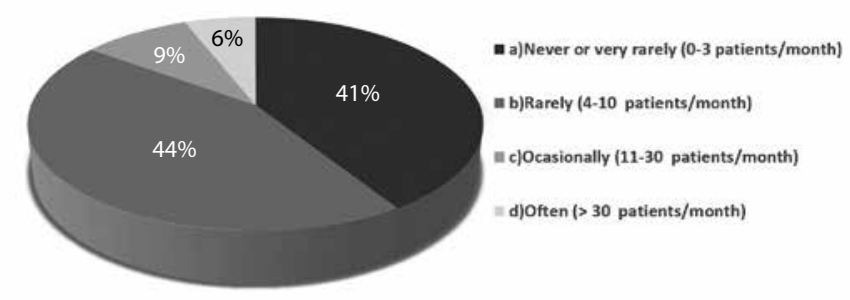

Figure 1. 85\% $(a+b)$ of Emergency physicians rarely or almost never evaluate the mental health of patient

had inpatient facilities for psychiatric patients. A psychologist and rehabilitation programs were found in less than $10 \%$ of the hospitals surveyed.

Pilot study: In the pilot study, 84\% (21/25) of EPs said their departments did not have a management policy for $\mathrm{MH}$ disorders and $92 \%(23 / 25)$ did not receive any training to handle $\mathrm{MH}$ disorders.

\section{Discussion}

This study showed that over $90 \%$ EPs have come across mentally ill patients. Most of them also agreed that MH disorders are a major healthcare burden (Table 1). This suggests awareness about disease burden exists and that $\mathrm{MH}$ related patient visits are not uncommon to EDs.

$85 \%$ of EPs rarely or never evaluate $\mathrm{MH}$ of patients (Figure 1 ). Assessment was mostly done for patients in whom the presenting complaint or behaviour was obviously indicative of a mental illness. This suggests that $\mathrm{MH}$ evaluation is a neglected aspect in ED domain. This also suggests that patients with an occult MH disorder may be not receiving adequate treatment as no screening is done.
More than $80 \%$ physicians said their ED has no management or referral policy for $\mathrm{MH}$ disorders and $82 \%$ said this is a major reason why evaluation of mental health is ignored (Table 2). Criteria for seeking a psychiatric referral and the discharge advice given to patients concerning their $\mathrm{MH}$ varied from EP to EP. Lack of clear guidelines or a protocol that helps in decision making were found to be main reasons for the inconsistencies in management and disposition of these patients.

Most of EPs haven't undergone any formal training in managing patients with $\mathrm{MH}$ disorders and over $75 \%$ say this is a reason why identification of mental illness in patients becomes difficult (Table 3). Over $2 / 3^{\text {rd }}$ EPs do not know any criteria of diagnosing depression and over $80 \%$ did not use any tool or scale to diagnose depression. This may be because psychiatry as a subject is not emphasised in the undergraduate period or ignored in the EDs. Less than $10 \%$ EPs quoted postgraduate curriculum and exams as training. This suggests EPs with only 1 year experience or having lesser qualifications are not getting trained in this aspect. It was also found that EPs who knew criteria of diagnosing depression were more likely to evaluate the mental health of patients (Table 4) suggesting the positive impact of training that can have on evaluation practices. Most of the multi-speciality hospitals have a psychiatrist but only during limited OPD hours. None of the hospitals surveyed had a mental healthcare professional available 24/7. This suggests that mental illnesses are not considered as medical emergencies by the management. Less than $20 \%$ hospitals surveyed had inpatient facilities for these patients and below $10 \%$ surveyed had a psychologist or mental rehab/ support programs. Mentally ill patients are considered as speciality cases and are referred to psychiatric hospitals.

Majority of EPs said that awareness about MH disorders is very poor in their ED staff and have felt that patients with mental illnesses were treated as unwelcome in ED. $60 \%$ EPs have experienced patients or their family members don't take the advice for a psychiatric referral kindly considering it unnecessary. $44 \%$ of EPs said their approach and attitude to patients with $\mathrm{MH}$ disorders is affected by their own personal experiences (Table 5). These observations suggest that underlying prejudice and stigma associated with mental illnesses may negatively impact overall management.

\section{Study limitations}

The results of this study were based on the individual responses of EPs and their understanding of their working environment. They may or may not depict the exact functionality of their departments. As such, separate studies are recommended within individual hospitals.

\section{Conclusion}

Mental health of patients is rarely assessed in EDs. Most of the EDs have no departmental policy on mental illnesses and EPs are not trained to handle $\mathrm{MH}$ related issues in patients. As such referral practices and the discharge advice given to patients regarding $\mathrm{MH}$ are inconsistent. EP's attitude to these patients is often influenced by their own personal experience. Most of the hospitals do not have adequate resources for mentally ill patients. Urgent actions are warranted at departmental and community level to create awareness about and to tackle this problem effectively. 


\section{Recommendations}

1) $\mathrm{MH}$ assessment and screening for mental illness should be done along with physical examination for all patients in the ED.

2) It is strongly recommended that a departmental MH policy is established.

3) Training of EPs and ED staff is mandated in managing $\mathrm{MH}-$ related issues in busy ED environments.

4) Provision of inpatient facilities and a $24 / 7$ on-call MH care professional should considered by all hospitals.

Ethics Committee Approval: Ethics committee approval was received for this study from the Institutional Ethics Committee of Apollo Hospitals (16.12.2016, Decision No: AHJ-025/12-16).

Informed Consent: Verbal informed consent was taken from the medical superintendent or the Head of the ED.

Peer-review: Externally peer-reviewed.

Conflict of Interest: No conflict of interest was declared by the authors.

Financial Disclosure: The authors declared that this study has received no financial support.

\section{References}

1. The world health report 2001 - Mental Health: New Understanding, New Hope; 2001 Available from: http://www.who.int/whr/2001/en/

2. National mental health policy of India. Available from: http://www. mohfw.nic.in/index1.php?lang=1\&level=2\&sublinkid=4723\&lid=2964

3. Kang HJ, Kim SY, Bae KY, Kim SW, Shin IS, Yoon JS, et al. Comorbidity of depression with physical disorders: research and clinical implications. Chonnam Med J 2015; 51: 8-18. [CrossRef]

4. Alboni P, Favaron E, Paparella N, Sciammarella M, Pedaci M. Is there an association between depression and cardiovascular mortality or sudden death? J Cardiovasc Med 2008; 9: 356-62. [CrossRef]

5. Rickards H. Depression in neurological disorders: Parkinson's disease, multiple sclerosis, and stroke. J Neurol Neurosurg Psychiatry 2005; 76(Suppl 1): i48-52. [CrossRef]

6. Negi H, Sarkar M, Raval AD, Pandey K, Das P. Presence of depression \& its risk factors in patients with chronic obstructive pulmonary disease. Indian J Med Res 2014; 139: 402-8.

7. Anderson RJ, Freedland KE, Clouse RE, Lustman PJ. The prevalence of comorbid depression in adults with diabetes a meta-analysis. Diabetes Care 2001; 24: 1069-78. [CrossRef]
8. Bautovich A, Katz I, Smith M, Loo CK, Harvey SB. Depression and chronic kidney disease: A review for clinicians. Aust N Z J Psychiatry 2014; 48: 530-41. [CrossRef]

9. Maass SW, Roorda C, Berendsen AJ, Verhaak PF, de Bock GH. The prevalence of long-term symptoms of depression and anxiety after breast cancer treatment: a systematic review. Maturitas 2015; 82: 100-8. [CrossRef]

10. Kumar A, Clark S, Boudreaux ED, Camargo CA Jr. A multicenter study of depression among emergency department patients. Acad Emerg Med 2004; 11: 1284-9. [CrossRef]

11. Frayne SM, Berg E, Holmes TH, Laungani K, Berlowitz DR, Pogach L, et al. Mental illness-related disparities in length of stay: algorithm choice influences results. J Rehabil Res Dev 2010; 47: 709-18. [CrossRef]

12. Chen YW, Dilsaver SC. Lifetime rates of suicide attempts among subjects with bipolar and unipolar disorders relative to subjects with other Axis I disorders. Biol Psychiatry 1996; 39: 896-9. [CrossRef]

13. National crime bureau record data on accidental deaths and suicide (ADSI) in 2014. Available from: http://ncrb.gov.in.

14. WHO intervention guide for suicide prevention. Available from: http:// www.who.int/mental_health/prevention/suicide/suicideprevent/en/

15. Biros MH, Hick K, Cen YY, Mann J, Gaetz A, Hansen R, Schiming R. Occult depressive symptoms in adolescent emergency department patients. Arch Pediatr Adolesc Med 2008; 162: 769-73. [CrossRef]

16. Thirunavukarasu M, Thirunavukarasu P. Training and national deficit of psychiatrists in India - a critical analysis. Indian J Psychiatry 2010; 52: S838. [CrossRef]

17. Gulliver A, Griffiths KM, Christensen H. Perceived barriers and facilitators to mental health help-seeking in young people: a systematic review. BMC Psychiatry 2010; 10: 113. [CrossRef]

18. Martínez-Hernáez A, DiGiacomo SM, Carceller-Maicas N, Correa-Urquiza M, Martorell-Poveda MA. Non-professional-help-seeking among young people with depression: a qualitative study. BMC Psychiatry 2014; 14 124. [CrossRef]

19. Loganathan S, Murthy SR. Experiences of stigma and discrimination en dured by people suffering from schizophrenia. Indian J Psychiatry 2008; 50: 39-46. [CrossRef]

20. WHO mental health GAP interventions guide. Available from: http:// www.who.int/mental_health/mhgap/en/

21. Khav N, Weiland TJ, Jelinek GA, Knott JC, Salzberg M. Depression Symptoms and Risk Factors in Adult Emergency Department Patients: A Multisite Cross-Sectional Prevalence Survey. ISRN Emergency Medicine, 2013, Article ID 965103, 8 pages, doi:10.1155/2013/965103. [CrossRef]

22. Hoyer D, David E. Screening for depression in emergency department patients. J Emerg Med 2012; 43: 786-9. [CrossRef]

23. National population census 2011. Hyderabad statistics. Available from: http://www.census2011.co.in/census/district/122-hyderabad.htm 